\title{
Volt egyszer egy praxisorientált képzési programterv a Rendőrtiszti Főiskolán (1994-1995)
}

\section{DÁNOS Valér ${ }^{1 \oplus}$} „Ahhoz, hogy az ember valami egész újat meglásson,
ahhoz egészen másképp kell gondolkodni. És ha az ember
másképp gondolkodik, azt mondják, hogy bolond."
Szent-Györgyi Albert

Ecikk szerzője 1994 és 1996 között volt a Rendőrtiszti Főiskola vezetője. Korábban maga is hallgatója volt az intézménynek, "vörös diplomával" végzett. Majd hét esztendőn keresztül oktatója, tudományos kutatója volt az intézménynek, és részese lehetett a komplex oktatási rendszer elnevezést viselő képzési program kidolgozásának, múvelésének. Közvetlenül a rendszerváltoztatást követően a Belügyminisztérium oktatásiszakterületvezetőjekéntfeladatavolta rendvédelmi oktatás-képzés megreformálása, az oktatással foglalkozó szervezetrendszer felügyelete. E három területen szerzett széles körü ismerete és tapasztalata predesztinálta arra, hogya Főiskola élére történt kinevezését követően „fenekestől felfordítsa" az addigi képzési rendszert, és az általa spekulatív tantervi elméleten alapuló képzésnek nevezett rendszer helyett egy teljes paradigmaváltást jelentő, praxisorientált képzési rendszert valósítson meg. Lelkesedése két esztendőn keresztül töretlenül vitte elöre elképzelésének megvalósításában. Szakmai meggyőződéssel és hittel vallotta, hogy az addigi, szocialista típusú ismeretalapú megközelités helyett a gyakorlatorientált (nevén nevezve praxisorientált) képzés bevezetésére van szükség. Az elképzelés kidolgozását, képzési programba való foglalását az akkori belügyminiszter - jelentős elismerés mellett - jóváhagyta. A néhány hónap múlva kinevezett új belügyminiszter a főiskolai parancsnok kinevezését megerősítette, és javaslata tantervbe foglalását elrendelte. Így tovább folytatódhatott a megkezdett innovációs munka a Főiskola vezetője mellett felsorakozó, az elképzelésével azonosuló, azt támogató lelkes csapat (többek között dr. Szakács Gábor, dr. Matei László, dr. Blaskó Béla, Révész István és mások) közremüködésével. Az alábbi cikkben a tudományosan megalapozott, széles körü, eddig nem publikált empirikus kutatások adatait is értékesító újtanterv megalkotásának állomásait, egyes föbb jellemzőit mutatom be. A szerző irásának végén arra is kitér, hogy az új képzési rend tantervéröl, valamint az új tanterv bevezetéséről szóló kormányrendelet-tervezetnek és a főiskolaparancsnoknak mi lett a további sorsa.

Kulcsszavak: rendőrtisztképzés, innováció, praxisorientáltság, jubileum, Rendörtiszti Főiskola

Dános Valér ny. r. vezérőrnagy, Belügyi Szemle főszerkesztő.

Valér Dános ret. Police Major General, Editor-in-Chief, Belügyi Szemle.

E-mail: valer.danos@bm.gov.hu 


\section{Az iránytü}

A praxisorientáltság gondolata nem gyökér nélküli, azt mélyen az elödjeim munkássága alapozta meg. Meggyőződésem, hogy két olyan meghatározó vezetője volt a Rendőrtiszti Főiskolának, akiknek munkássága igen nagy hatással volt az általam megkezdett képzéskorszerüsítésnek az 1990-es évek közepén. E két intézményvezető dr. Györök Ferenc és dr. Kratochwill Ferenc volt.

A Rendőrtiszti Főiskola (Főiskola) alapító parancsnoka, dr. Györök Ferenc rendőr vezérőrnagy nevéhez kapcsolódik a komplex képzési rendszer megalkotása. Jóllehet iskolateremtő tevékenységéról már sokan megemlékeztek, mégis fontosnak tartom, hogy azokat a reformelképzeléseit vázlatosan érintsem, amelyek a rendőrtisztképzéssel kapcsolatos nézeteimet megalapozták, de legalábbis alakították. Györök Ferenc a közel 20 éves vezetése alatt szinte nap mint nap újat és még újabbat alkotott, lépésről lépésre építette fel a rendőrtisztképzés struktúráját. Talán nem túlzás kijelenteni, hogy a Főiskola életében az egyik leginnovatívabb képzésfejlesztő volt, aki megszállottan törekedett az oktatási rendszer folyamatos megújítására, javítására, új lehetőségek keresésére és kiaknázására. A Főiskola képzési rendszere az 1972-es indulásakor döntően a „jogelődje”, nevezetesen az 1960-ban létrejött Rendőrtiszti Akadémia ${ }^{2}$ és a szovjet rendőrtisztképzés hagyományaira, valamint tapasztalataira épült. Györök Ferenc így emlékszik vissza erre az időszakra:

„Legfontosabb feladatunk a képzési cél és a tanterv kialakítása volt, amelynél messzemenően építettünk a Rendőrtiszti Akadémia hagyományaira, gazdag tapasztalataira. 1970 novemberében Moszkvába és Kijevbe utaztunk, ahol nagyon sok hasznos tapasztalatot szereztünk az új tanintézet megszervezéséhez. Decemberben egy szovjet szakember érkezett hozzánk, aki három hónapig segítette előkészítő munkánkat."3

A Főiskola megalakulásakor a tantervben kiemelkedő súllyal szerepeltek az úgynevezett marxista-leninista múveltséget biztosító tantárgyak, valamint a jogi múveltséget megalapozó tantárgyi csoport. Ez utóbbi tantárgycsoport miatt - kissé gúnyosan - az ELTE Állam- és Jogtudományi Kar kistestvérének is nevezték a Főiskolát, amihez nagymértékben hozzájárult a tanári törzs összetétele is, így többek között dr. Kovacsics József, dr. Berényi Sándor, dr. Számel Lajos, dr. Vigh József, dr. Pintér Jenő, dr. Bodgál Zoltán, dr. Horváth Tibor, dr. Kratochwill Ferenc jelenléte.

Györök Ferenc munkásságának szinte paradigmaváltást jelentő újításaként 1978-ban megkezdődött a „komplex oktatási rendszer” kidolgozására irányuló munka, amelynek középpontjában a gyakorlatorientált, témacsoportos megközelítésủ tanterv állt. Magam mint a Főiskola volt hallgatója és frissen kinevezett oktatója, nagy

2 A BM. Rendőrtiszti Akadémia felállításáról szóló, a Magyar Népköztársaság belügyminiszter helyettesének 1960. február 6-án kelt 009. számú utasítása.

3 Nyerges Lajos: Körinterjú a Belügyminisztérium munkájának fejlődéséről (1945-1980). Belügyi Szemle, 18. (1980), 4. 40 . 
lelkesedéssel vettem részt ebben az alkotó folyamatban. Ma is szakmai hittel vallom, hogy a gyakorlati, a valós életre történő felkészítésre irányuló új elképzelés az adott időszak legkorszerúbb, szinte forradalmi jellegű paradigmaváltása volt a magyar felsőoktatás palettáján. Néhányan ugyan nem voltak képesek elfogadni az új módszert, elsősorban az elméleti tantárgyakat oktatók ellenezték annak bevezetését. „A képzés azonban nem hozta meg a várt eredményt, a hallgatók nem új minőségú ismereteket szereztek, csak egy időben tanultak egy témakörhöz tartozó különböző tudományterületi ismereteket, a belső összefüggések kialakulása nélkül, illetve szintetizált ismeretek helyett csupán kétszer annyi anyagból vizsgáztak."” Azok az oktatók azonban, akik az úgynevezett szakmai tantárgyakat, valamint az egyes tantárgyak „különös részét” oktatták, nagy örömmel fogadták Györök újítását, felismerve, hogy a módszer a valós gyakorlati életet hozta be a Főiskolára.

A következő, mértékadó vezető a Főiskolán közvetlen elődöm, a jogász végzettségű dr. Kratochwill Ferenc volt. Kratochwill rendkívül értékes gondolatokat fogalmazott meg jó néhány írásában a rendőrtisztképzéssel kapcsolatban. ${ }^{5}$ Bár mi nem dolgozhattunk együtt, az utódokra hagyott írásai iránytűt jelenthettek valamennyi utána következő intézményvezető számára. Jogászi indíttatásából következően teljesen új profilt kívánt adni a Főiskolán folyó oktatásnak. Kratochwill Ferenc határozott elképzelése szerint ugyan nagyobb hangsúlyt kell fektetni a szakmai ismeretek mélyebb elsajátítására, de ezzel párhuzamosan kiemelten fontosnak tartotta a rendőrtisztek kulturális színvonalának ügyét, valamint az ismeretalapú képzés jelenlétét a Főiskola tekintetében is. Utolsó írásainak egyike, $A$ rendörség szakmai és kulturális színvonala, a rendőrképzés címet viselő feljegyzés volt - amely korai halála miatt már nem jelenhetett meg folyóiratban - valóságos üzenet volt utódjai felé. Ebben az írásában a négyéves tisztképzés, a képzési idő legalább egyharmadát kitevő gyakorlati képzés, a tiszti továbbképzés és a vezetőképzés egységes rendszerbe foglalása jelent meg: „A tisztképzés a polgári pályázók számára 4, a belső (rendőr) pályázók számára 3 éve. Általános jellegư tisztképzés, de lehetővé teszi a képzési idő 1/3-ában a hallgatók szakosodását." ${ }^{\prime}$

Az előzőekben megfogalmazott gondolatoknak azért is tulajdonítok kiemelt jelentőséget az írásomban, mert ezek szolgáltak iránytűként az 1994. év elején általam meghirdetett „praxisorientált” képzési rendszer kidolgozása során, amelyről a továbbiakban részletesen írok.

Schubauer László: Büntetőjog oktatása a rendészeti képzésben. Magyar Rendészet, 14. (2014), 1. 21-26.

Györök Ferenc - Kratochwill Ferenc - Nyerges Lajos: A Rendőrtiszti Főiskola múltjáról, jelenéről és jövőjéről. Rendészeti Szemle, 30. (1992), 12. 46-52.

6 Kratochwill Ferenc: A rendốrség szakmai és kulturális színvonala, a rendôrrképzés. Kézirat. Budapest, 1993. 8. 


\section{A paradigmaváltást jelentő praxisorientált rendőrtisztképzés koncepciója}

Amint azt az előző részben írtam, két olyan hagyaték állt rendelkezésemre a Főiskola élére történt kinevezésemkor, amely alapvetően meghatározta a Főiskola jövőbeni működtetésére irányuló, a belügyminiszter részére készített előterjesztésem szellemiségét és tartalmát. A Györök-féle gyakorlatra fókuszáló komplexitás és a Kratochwill-féle, döntően ismeretelméletre épülő képzési rendszer. E két szellemiségű, látszólag összeegyeztethetetlen elvi dilemmával kellett megküzdenem: működhet-e egy rendészeti felsőoktatási intézmény valóságos főiskolaként, miközben olyan kimeneti követelményeknek is meg kell felelnie, amelyek feltételezik, hogy a Főiskola befejezését követően a munkába lépő tisztre azonnal lehet „szignálni” ügyeket. A megoldást abban láttuk, hogy olyan rendvédelmi „szakértelmiséget” bocsássunk ki az intézményből, amelynek tagjai egyszerre rendelkeznek azokkal az ismeretekkel, amelyek elősegítik az értelmiségi körbe való gyors alkalmazkodást, és a végzettek egyúttal rendelkeznek azzal a szakmai gyakorlati tudással, amely alapján teljes értékű munkát tudnak végezni a munkába állásukat követő rövid időn belül. Az alapkoncepció miniszteri jóváhagyását követően azonnal megkezdődött az a széles körű empirikus oktatástechnológiai és módszertani kutatás, amilyenre mind a mai napig nem került sor a rendőrtisztképzés életében.

\section{A praxisorientált képzési rendszert megalapozó empirikus kutatás}

Első lépésként a vonatkozó szakirodalom részletes feltérképezését végeztük el, amely során áttekintettük a releváns hazai és nemzetközi általános és rendvédelmi szakmai felsőoktatás akkori trendjeit, különös figyelmet fordítva a rendőrtisztképzés sajátosságaira. E helyen csupán egyetlen, a gondolkodásunk irányára kiemelkedő hatású megállapítást emelek ki: a rendőrtisztképzést végző külföldi tanintézetek többsége egyszerre kívánt megfelelni a testi, a személyiségi, a szakmai és az intellektuális képzés követelményeinek. A követelmények spekulatív alapon történő definiálása miatt szinte egyetlen egy követhető mintát sem tudtunk felállítani, mert általánosan hiányzott az az előrelátás, amely az említett (alkalmassági és kimeneti) követelményeket konzekvensen végigvezette volna a belépéstől a kilépésig bezárólag. A képzési rendszerek tervezésénél még nem vették figyelembe a civil felsőoktatásban akkor helyenként már ismert kompetenciaalapú tantervelmélet téziseit. A legfőbb problémának azt véltük, hogy a tanintézetek sem az input oldalon sem pedig a tanulmányi előmenetel során nem szelektálnak, hanem a pályaalkalmasság eldöntését a végzés utáni praxisra hagyják.

Második lépésként - a majdani kérdőíves felmérés előkészítése érdekében - interjús felmérésre került sor, amely során interjúalanyként a Főiskola akkori tanárait, 
hallgatóit, a rendőrségi vezetőket, valamint a Főiskolán diplomát szerzett és a kérdezés időpontjában a szakmában dolgozó rendőrtiszteket kérdeztük meg.

A négy csoport tíz-tíz tagja által alkotott vélemények alapján dolgoztuk ki a kérdőív struktúráját, és állítottuk össze a kérdéseket. Tekintettel arra, hogy már az interjú során beigazolódott a csoportképzés helytállósága, a kérdőíves felmérés alanyait is e csoportokba rendezve vizsgáltuk. A felmérésbe az 1990-es évek egyik meghatározó oktatásszociológiai kutatóintézetének (Szocio-reflex Kft.) két elismert kutatóját vontuk be.

A mintasokaságot összesen 470 fő alkotta az alábbiak szerint (megszólítottak/válaszadók száma): I. oktatók: 70/70, II. hallgatók: 150/150, vezetők: 100/96, végzettek: 150/149. Ugyancsak fontos információ keletkezett a Főiskola tanárai által 1994 áprilisában kitöltött kérdőíves felmérésből. E felmérés célja az volt, hogy megismerjük az oktatók véleményét egy átfogó reformról, valamint egy új oktatási koncepció kialakításának jellemzőiről. A megszólított összes tanár (166 fő) 69, 28\%-a (115 fő) töltötte ki a kérdőívet.

„A véleményüket közreadó tanárok többsége a szakfőiskolai jelleg erősítése és a gyakorlatiasabb képzés megvalósítása mellett szállt síkra. A felvetések egy része a nevelő-oktató munka egész struktúrájának gyökeres megváltoztatására, másik hányada egyes tantárgyak oktatásának életközelibbé tételére, míg a harmadik csoportja az elméleti és a gyakorlati képzés összhangjának megteremtésére irányult.”

A felmérés legfontosabb üzenete az volt, hogy az oktatói kar nagy többsége elfogadta az új vezetés által előzetesen közzétett általános elképzeléseket, és nyitott volt új szempontok és megközelítési módok befogadására, különös tekintettel a gyakorlatiasság előtérbe helyezésére.

Az empirikus kutatásból származó adatokat emlékezetem szerint az akkor igen modern statisztikai adatfeldolgozást támogató alkalmazással, a DOS-os SPSS /PC program segítségével dolgoztuk fel, amely alkalmas volt már különböző táblázási munkákra, így a táblacellák - százalékok, átlagok - közti különbségek és szignifikanciák megjelenítésére is.

\section{A praxisorientált képzési rendszert megalapozó empirikus kutatás}

Jelen fejezetben a rekrutáció, a kiválaszt(ódás) problémájával, a képzési folyamattal, a főiskolára felveendő létszámmal, továbbá egyes elméleti és gyakorlati ismeretek fontosságával illetőleg azok megítélésével foglalkozom.

Szakács Gábor: Összefoglaló jelentés a Rendôrtiszti Fôiskola tanárai által kitöltött kérdôívekben szereplő véleményekről. Kézirat. Budapest, 1994. 4. 


\section{A rekrutáció, a kiválaszt(ód)ás problémája}

Valamennyi csoportban az a vélekedés volt megállapítható, hogy a jelentkezők nagy részét máshova valószínúleg nem vették volna fel, és itt szerezhető meg a legkönynyebben a diploma, valamint az, hogy a megkérdezett csoport körében az úgynevezett egyenruhás karrierképzet vezethette a jelentkezőket erre a pályára. A vonatkozó kérdésekre adott válaszok nyomán arra az álláspontra jutottunk, hogy a rendôri pálya igen magasfokú komplexitása erőteljesen megnehezíti az objektív szelekció szempontrendszerének összeállítását, és nem az alkalmasak kiszúrésére irányul a felvételi rendszer, hanem az "alkalmatlanokat” tartja távol a képzéstől. Utólag már tudjuk, hogy az, aki nem felel meg a felvételin, nem biztos, hogy alkalmatlan, és fordítva, aki ugyan teljesíti a felvételi szint követelményeit, nem biztos, hogy egyúttal alkalmas is a rendőri munkára. Az akkori felvételi rendszer csupán azt jelezte felénk, hogy a felvételiző alkalmas-e a főiskolai tanulmányok megkezdésére, vagy sem.

Érdekes eredmény született annak a kérdésnek a vizsgálatakor, amikor is arra kerestük a választ, hogy milyennek tartják a megkérdezettek a felvételi rendszert, és szerintük milyennek kellene lennie. Ezzel kapcsolatban valamennyi válaszadó csoportban első helyen szerepelt az intelligencia felmérését célzó vizsgálat, és csupán a középmezőnyben szerepelt a lelki-mentális beállítottság, a pálya iránti attitűdök mérése. A másik, ma is érvényes megállapítást a hallgatói válaszok generálták, amikor is a felvételi rendszert igazságtalannak, túlzottan elméleti jellegűnek minősítették, és a rendőri pályára való alkalmasság mérésének hiányát hangsúlyozták. E kérdésben nyilvánvalóan nagy szerepe van a pályaképnek, pontosabban a pályaismeretnek, mert csak ez alapján lehet e vélekedést értelmezni. A pályaismeret fontosságára - bár más összefüggésben - Christián László és Erdős László is felhívja a figyelmet: „Megfelelő pályaismeret hiányában a fiataloktól nem várható realitásokon nyugvó döntés meghozatala."

\section{A képzési folyamat és annak megitélése}

A kérdőív megszerkesztésekor a már rendelkezésre álló információk és feltárt adatok alapján a kutatás vezetői meg voltak győződve arról, hogy a praxisorientált képzésre történő átállás esetén nem lesz elegendő a hároméves képzési idő, a gyakorlati foglalkozások óraszámának emelése miatt át kell térni a négyéves képzésre. Ezért már az első kérdés rögtön a négyéves nappali képzés időtartamának megítélésére vonatkozott. A tanárok és a területen dolgozó tisztek csoportjába tartozók négyötöde tartotta szükségesnek a képzési idő meghosszabbítását, ugyanakkor a hallgatók csak alig több mint a fele értett egyet a négyéves képzés bevezetésével. Ez utóbbira a magya-

\footnotetext{
Christián László - Erdős Ákos: Vészharang és jubileum? A rendészeti felsőoktatás kilátásai, a tisztjelöltek toborzásának és életpályára állításának nehézségei. Belügyi Szemle, 68. (2020), 12. 29.
} 
rázatot a nyitott kérdésekre adott válaszokból kaptuk meg: a leendő rendőrtisztek többsége minél hamarabb szeretne kikerülni a Főiskoláról, és szeretné megkezdeni a gyakorlati munkát.

E kérdés vizsgálata mindmáig időszerü: még agitatív érvként sem tudom elfogadni ma sem azt a választ, amely kizárólag az ismeretek megnövekedésével magyarázza a képzési idő emelésének szükségességét.

\section{A Fôiskolára felveendő létszám megítélése}

Érdekes következtetés volt levonható az évente „beiskoláztatási” létszám meghatározására vonatkozó kérdésre adott válaszokból. A rendőrségi vezetők, valamint a már gyakorlatban dolgozó, főiskolát végzett tisztek a hallgatói létszám jelentős növelését szorgalmazták, a hallgatók és a tanárok viszont nagymértékben csökkentenék az évfolyamok létszámát. Ez utóbbi két csoport véleménye feltehetően a rendőri munka presztízsével hozható összefüggésbe, ami a rendőrtiszti pálya professzionalizálódásának kérdéséhez vezet át. Objektíve is igaz, de magam teljes meggyőződéssel vallom, hogy a rendőrtiszti pálya (mint foglalkozás) olyan felsőfokú (és nem biztos, hogy kizárólag felsőoktatásban megszerezhető) végzettséget monopolizál, amelynek központi eleme a professzió. Számomra a professzió ebben az értelemben azt jelentette, hogy a rendőrtiszti végzettséget ne lehessen más diplomával helyettesíteni, a rendőrtiszti pálya saját oktatási, képzési és továbbképzési rendszert alakítson ki magának, végül iktassa ki szakterületéről a laikus, politikai színezetű kontrollt, de építse ki a külső, sajátos szakmai kontrollszervezetek rendszerét. Tehát ebben a felfogásban a rendőrtiszti pálya mint professzió sajátos privilegizált kategóriaként jelenhet meg a társadalmi munkamegosztás rendszerében, ahol a professzionálisok tudása a sajátos szemléletből, képzésből és a sajátos gyakorlatból (praxisból) tevődik össze. A kutatás adatai ezt annyiban támasztották alá, hogy főleg a hallgatók körében volt tapasztalható az az igény, amely szerint korlátozni kívánják a más felsőoktatási intézményből történő átjelentkezéseket, erősen gyakorlatorientált képzést igényelnek, a felvételi követelmények között a rendőrtiszti pályára való alkalmasság mérését preferálják, és a tanulmányaik során is úgynevezett minőségi alkalmassági szűrők beiktatását sürgetik. A vezetők és a tisztek csoportjába tartozók közül többen felvételi kritériumként írnák elő az előzetes gyakorlati munka meglétét, ami ugyancsak a professzionalizálódás felé mutató jegyként értelmezhető.

Fontos megjegyeznem, hogy sem a Belügyminisztérium vezetése, sem az akkor hivatalban lévő rendőrfőkapitány nem avatkozott bele direkt módon a felveendő létszám meghatározásába, tekintettel arra, hogy abban az időben nem volt jelentősebb tiszthiány a rendőrségnél. Így a felveendő létszámot alapvetően a Főiskola rendelkezésére álló humán és materiális infrastruktúra, valamint a központi költségvetési támogatás mértéke határozta meg. 


\section{Az egyes elméleti és gyakorlati ismeretek fontosságának megítélése}

A kutatás legérdemibb kérdéscsoportja kétségkívül a tantárgyak, pontosabban az egyes ismeretek elsajátításának fontosságára irányult. A sorrendet az egyes kérdésekre adott 1-5 közötti osztályzatok és a százalékos megoszlások alapján állapítottuk meg, külön-külön a válaszadók csoportjaira is bontottan.

A vizsgálat tárgyává tett, igencsak nagyszámú tantárgyat (36 tantárgy) a könynyebb elemzés, kezelhetőség és értelmezés érdekében faktoranalízisnek vetettük alá, aminek következtében három tantárgycsoportot (ismeretfaktort) alkottunk: értelmiségképző tantárgycsoportfaktort, elméleti szakmai tantárgycsoportfaktort, gyakorlati szakmai tantárgycsoportfaktort. Az így csoportosított tantárgyak együttes osztályzatai, az úgynevezett faktorszkórok valamennyi válaszadó esetében önálló véleménystruktúrát képviseltek. Ennek köszönhetően lehetőség nyílt az egyes faktorok (tantárgycsoportok) eredményeinek - a különböző válaszadói csoportokban történő - értékelésére. Mindenekelőtt le kell szögeznem, hogy a felmérés és a kiértékelés 1994-ben történt, ezért a megállapításainknak kevés üzenetértéke van a mai oktatásfejlesztők számára. Kevés, mert egyrészt az akkori fogalmak tartalma, a tantárgyak és a készségek elnevezése más volt, mint ma, másrészt a rendszerváltoztatás közelsége miatt néhány akkor használt fogalom, kifejezés jelentéstartalma komoly változáson ment keresztül. Azt is hangsúlyozni szükséges, hogy a mai rendőrségnek teljesen más kihívásokkal kell szembenéznie, mint az 1990-es évek első felében.

Attól függően, hogy a faktorszkór negatív vagy pozitív értéket mutat, megállapítható, hogy az adott válaszadói csoport mennyire kötődik az adott faktorhoz. Tekintettel arra, hogy a válaszadók elsősorban az akkor hatályos tantervről és az azt alkotó tantárgyakról mondtak véleményt és minősítést, minél negatívabb értéket mutat a faktorszkór, annál inkább kevésbé tartják fontosnak a főiskolai képzés tekintetében az adott tantárgycsoportot, és minél pozitívabb a faktorszkór értéke, annál fontosabbnak ítélik meg az adott faktort.

Az értelmiségképző tantárgycsoportfaktort a tanárok (különösen a bölcsész végzettségű nyelvtanárok) értékelték magasra, vagyis megfelelőnek, és a hallgatók értékelték legalacsonyabbra, kevésbé fontosnak. A hallgatók a gyakorlati szakmai tantárgycsoport fontosságát értékelték a legmagasabbra, legfontosabbnak, a vezetők és a tisztek is az elégedetlenségüket fejezték ki ez utóbbi tantárgycsoport akkori helyzetével. Ez a megítélés - az interjúk alapján - azzal hozható szoros kapcsolatba, hogy a főiskolai gyakorlat igen távol állt a területi gyakorlattól, azt többen „lombik” gyakorlatnak minősítették. A hallgatók e mellett érdekesebbnek tartották a gyakorlati foglalkozásokat, mint az elméleti órákat. Ezek az adatok rendkívül fontos támpontot képeztek a tanterv gyakorlatorientált jellegének kialakításában.

A továbbiakban vizsgáltuk az „ideális rendőrtiszt” jellemzőit, 30 „tulajdonságot” érintve. A tulajdonság kifejezést mint gyűjtőfogalmat használtuk, és bekerült e csoportba olyan ismérv is, amely a mai felfogásunk szerint talán furcsán hangzik, és a felmérést végzők e tekintetben vett laikusságára utal (szigorúság, humorérzék, türelem, 
rábeszélő képesség). A válaszok alapján az ideális rendőrtiszt képe igen erős konszenzust hordozott magában, és mindegyike magas átlagosztályzatot mutatott. Nyolc olyan tulajdonság szerepelt felmérésünkben, amelyek mindegyike az ötfokú skála felső határához közel esett, jelezve a megítélés viszonylagos egyenszilárdságát. Ezek a következők voltak: határozottság, beszédkészség, rugalmasság, kapcsolatteremtő készség, a jó modor, a szintetizáló készség, az empátia és az általános múveltség. E rendkívül sok tulajdonságot ugyancsak faktoranalízis alá vetettük, amely vizsgálatnak az egyik legfontosabb megállapítása az volt, hogy a „szabályzatkövető” véleménystruktúrába tartozó tulajdonságok a hallgatók és a hallgatói státuszt a közelmúltban elhagyók körében voltak kevésbé vonzók, és a kapitányok, valamint a tanárok tartották a legfontosabbaknak. A hallgatók negatív vélekedése egybeesik azzal az örökzöld hallgatói panasszal, amely az alakiság túlzott elvárásairól szól.

Összességében az a következtetés volt levonható az ideális rendőrtisztet jellemző véleményekből, hogy az értékpreferenciák nem annyira a gyakorlathoz kötődnek, hanem inkább a régebbi értékek fennmaradását jelzik egy új, alternatív értékkel szemben. Ez a megállapítás alapozta meg azt a szélesebb körű egyeztetési igényünket, amely a kialakítandó tanterv hatásvizsgálatára irányult. Ezért is jött létre a fóiskolai vezetést támogató oktatási és tudományos tanácsadó testület.

Egy újabb kérdéscsoportban arra kerestük a választ, hogy a megkérdezettek menynyire várnak el bizonyos feladatokat a főiskolai képzéstől, és milyen mértékben elégedettek azzal. E helyen csupán egyetlen egy szempontot emelek ki, amely a szakmai gyakorlathoz kapcsolódik. A válaszok váratlan eredményt mutattak, mert nem csupán a kapitányok és a tisztek, de maguk a tanárok is elvárják a Főiskolától, hogy erős szakmai gyakorlatot adjanak a hallgatóknak, ugyanakkor e feladat végrehajtásának tényleges eredményességét valamennyien lepontozták.

Amennyiben az előzőekben ismertetett felmérések, vizsgálatok összegzett eredményeit a professzionalizálódással kapcsolatban értelmezzük, az a következtetés vonható le, hogy leginkább a hallgatók körében körvonalazódik az a fajta szakismereti kör, amelyet csak és kizárólag a Rendőrtiszti Főiskola adhat a rendőri pályát választóknak. Tekintettel arra, hogy a vizsgálatunk eredményei alapján úgy láttuk, hogy a tanárok voltak legkevésbé tisztában a professzionalizálódás irányába mutató tendenciával, az egyik legfontosabb feladatunknak azt tekintettük, hogy már a tantervi

fejlesztés előkészítő fázisában is igen erőteljesen vonjuk be őket a közös tervezésbe, ne csupán a végső vagy közbenső véleményezésbe.

\section{A praxisorientált képzési rendszer új tantervének struktúrája és dilemmái}

Az előzőekben ismertetett rendkívül gazdag információ feldolgozása több mint egy esztendőt vett igénybe, az új tanterv kidolgozására és véleményeztetésére közel féléves időtartamra volt szükség. A kidolgozás során az egyik legnehezebb feladat annak 
a kérdésnek a megválaszolása volt, hogy a főiskolai képzés a generalista vagy a specialista irányba mozduljon-e el. Az akkori civil felsőoktatási trend a konvertálható tudás és az univerzitász jellegú elképzelések felé haladt. Gyakorlatilag ennek az irányzatnak felelt meg a Főiskolán folyó generalista képzés, amelyet igen erőteljesen igényelt az akkori rendvédelmi szervek nagy többsége. A rendőri vezetés nyilvánvalóan abban volt érdekelt, hogy a Főiskoláról kikerülő tisztek bármelyik szolgálati ág tekintetében azonnal bevethetők legyenek, illetve a horizontális mozgáshoz szükséges alapos szakmai ismeretekkel rendelkezzenek. E megoldhatatlannak tűnő dilemmát a főiskolai vezetés úgy próbálta feloldani, hogy a bevezetendő új képzési rend egyszerre feleljen meg a generalista és a specialista képzési ideának. Ehhez azonban szükséges volt a hároméves képzési időt - felmenő rendszerben - négyévesre felemelni. Az első három év, a képzés tartalmát illetően a generalista képzésnek felelt volna meg, a negyedik év pedig a specialista képzés követelményeit volt hivatva biztosítani. A Főiskola vezetése a rendőrség vezetőitől csupán azt kérte, hogy a harmadik év végére valamennyi hallgató esetében jelölje ki a végzés utáni konkrét szolgálati ágat és helyet.

$\mathrm{Az}$ új képzési rendszer szerint a Főiskola mint a magyar felsőoktatási rendszer része, a rendvédelmi felsőoktatás területén alapképzést, szakirányú továbbképzést, vezetőképzést, valamint vezetői továbbképzést kívánt ellátni. A fejlesztőcsoport a fejlesztés első lépéseként a praxisorientált alapképzés tantervét célozta meg elkészíteni, majd az erre szervesen épülő, mintegy integrált, több elemből álló továbbképzési rendszert képzelt el. A dilemmát az okozta a fejlesztők részére, hogy a továbbképzési rendszer beépülhet-e valóságosan a Főiskola képzési rendszerébe, avagy meg kell-e hagyni azt az egyes rendvédelmi szervek hatáskörében.

\section{Az új képzési rendszer tantervének általános jellemzői}

A fejlesztőcsoport elképzelése szerint az új rendszerű alapképzés nappali, levelező és távoktatási tagozatokon valósult volna meg büntetés-végrehajtási szak, határrendészeti szak, nemzetbiztonsági, rendőri és biztonságvédelmi (rendőri és biztonságvédelmi szakiránnyal), valamint vám-és pénzügyőri szakokon és szakirányokkal.

Az elképzelt képzési rendszer egyik újdonsága volt a rendőri-biztonságvédelmi szakon belül a biztonságvédelmi szakirány megalapítása, amely a civil szféra részére kívánt biztonságvédelmi szervezőket képezni, akik a magánnyomozói, a személyés vagyonvédelmi, a biztonságtechnikai és az egyéb biztonságvédelmi tevékenységekkel kapcsolatos feladatok végrehajtására, tervezésére, szervezésére és irányítására egyaránt képessé válnak. Ezt azért láttuk fontosnak, mert a hazai képzési rendszerben igencsak kaotikus képet mutatott a biztonsági magánszektorban a munkakör-specifikus felkészítés állapota. A másik ezzel kapcsolatos dilemma az volt, hogy a vonatkozó képzési rendszer kizárólagos állami monopóliumot képezzen-e, avagy azt a piac szereplőire (például a Kamarára) kell-e bízni. 
Ugyancsak új eleme volt az eltervezett képzési rendszernek a távoktatás speciális formájának bevezetése a Főiskolán. E képzési formában részt vevő hallgatók képzésének tartalma - néhány kivételtől eltekintve - megegyezett volna a levelező tagozaton részt vevő hallgatókéval. Ezért ez a kérdés a továbbiakban már csak oktatásmódszertani kérdésként vetődött fel, és az elképzelésünk szerint annak bevezetése előtt egy többszintű oktatástechnológiai és módszertani kutatást vezettünk volna be, illetve egy kifejezetten empirikus hatásvizsgálatot végeztünk volna. További jellemzője az új képzési rendszernek az volt, hogy a levelező és a távoktatási tagozatokon a tantárgyak köre és aránya - az egyenszilárdság biztosítása érdekében - megegyezett volna a nappali tagozatéval azzal a kivétellel, hogy e két tagozaton az idegen nyelv, a védelmi-önvédelmi, a kiképzési ismeretek és a fakultatív tantárgyak oktatására nem került volna sor.

\section{Az új képzési rendszer tartalma}

Az új tanterv egyik lényeges újdonsága a képzés időtartama tekintetében következett volna be. A képzés időtartama ugyanis a nappali tagozaton négy évre, nyolc szemeszterre növekedett volna. A képzési idő növelésének indoka természetesen nem az volt, hogy az új ismeretek mennyisége követelte volna ki magának az óraszám emelését, hanem kizárólag a praxisorientált elv érvényesítése érdekében a szakmai-gyakorlati foglalkozások óraszámának megemelése kívánta meg a négyéves képzésre történő átállást. A másik újdonság a célspecifikus gyakorlatok bevezetése volt. E szerint a hallgatók a harmadik év végét követő nyári gyakorlatot annál a szolgálati ágnál teljesítik, ahol a végzést követően munkába állnak. A negyedik évfolyam második félévében, azaz a nyolcadik szemeszterben összefüggően pedig 480 órát annál a szervezetnél, azon belül pedig konkrétan annál a szervezeti egységnél tölti el a hallgató a szakmai területi gyakorlatát, amelyet a személyi határozatában majd meghatároznak részére.

Természetesen ennek okszerű következménye volt a tantárgystruktúra és az egyes tantárgyak ismeretanyagának alapos újragondolása. Ennek eredményeként a tantárgyakat öt tantárgyi csoportba soroltuk: az úgynevezett értelmiségképző tantárgyi csoport, a szakképzést elősegítő tantárgyak csoportja, a szakképzést biztosító tantárgyi csoport, a rendvédelmi kiképzési tantárgyi csoport, végül a területi szakmai gyakorlatok csoportja. Az utóbbi három tantárgyi csoport óraszámának aránya az összképzés tekintetében minimum 75\%, maximum 85\% lehetett. Mindez jól reprezentálja az elképzelt praxisorientált képzés megvalósítására irányuló törekvéseket. A főiskolai hallgatóknak az új tanterv által előírt intézményi óraterhelése a heti 30 tanórát, a területi szakmai gyakorlatokon pedig a heti 40 munkaórát nem haladhatja meg. A tantervben a nappali tagozatos hallgatók részére a 7. félévben a szakdolgozatok elkészítéséhez - a tartalék időkeretből - egy oktatási hét lett volna biztosítva.

A tanterv tantárgyai a kötelezó és a fakultatív tantárgycsoportokba lettek besorolva, amelyek részletes felsorolását a tantervi táblázatok tartalmazták. A fakultatív 
tantárgyak köre az igények és a képzéssel szemben támasztott elvárások változásainak függvényében a Főiskolai Tanács döntése szerint folyamatosan változhat majd. A tanterv rugalmasságának másik elemeként határoztuk meg, hogy az egyes tantárgyakra vonatkozó részletes követelmények - bár a tanterv részét alkotó tantárgyi programok és tematikák tartalmazták - a tantárgy tartalmának 20\%-át meg nem haladó módosítás esetén az érintett tanszék kollektívájának döntése alapján, a 20\%-ot meghaladó módosításkor pedig a Főiskolai Tanács jóváhagyásával szintén változhatnak.

$\mathrm{Az}$ új praxisorientált képzési rendszer képesítési követelményeinek jellemzőiből e helyen mindössze annyit emelek ki, hogy azokat a mai szóhasználattal élve már kompetenciaalapon fogalmaztuk meg, így követelményként azt határoztuk meg, hogy az általános és a szakmai ismeretek jártassági és készségszintủ elsajátítása történjék meg a négyéves képzés ideje alatt.

\section{Összegzés}

Bátran kijelenthetem, hogy 1994-re, a Rendőrtiszti Főiskola élére történt kinevezésem idejére már meggyőződésemmé vált, hogy nem kellő mértékben gyakorlatias a magyar rendőrtisztképzés. Éppen ezért az akkori időben modernnek számító, úgynevezett szükségletközpontú tantervszerkesztésbe kezdtünk néhány munkatársammal. Azért nyúltunk ehhez az új módszerhez, mert amikor - a korábbi gyakorlatnak megfelelően - megkérdeztük a rendőrség, a határőrség, a tűzoltóság, a büntetés-végrehajtás vezetőit, hogy milyen tisztekre van szükségük az adott rendészeti területen, a válaszokban különböző módon körülírták a „jó” tiszt jellemzőit, az „ideális” tiszt fontosabb és kevésbé fontos ismérveit. Be kellett látnom, hogy ezekre az információkra nem lehetett alapozni egy új, a kor követelményeinek mindenben megfelelő tantervet. Erre tekintettel magunk kezdtünk hozzá ahhoz a vizsgálatsorozathoz, amely a rendészeti munka reális szükségleteit kívánta feltárni. Végül is a vizsgálataink annak megállapítására irányultak, hogy a rendészeti tisztek napi munkájuk során milyen konkrét feladatokat látnak el, és ehhez milyen szakismeretre, tudásanyagra, képességekre, készségekre - mai kifejezéssel élve: kompetenciákra - van szükségük. Végezetül csupán zárójeles gondolatként utalok az egyik

„vizsgálatunk azon megállapításaira, hogy az akkori tiszti munkakörök feladatainak csupán mintegy egyharmada volt un. tipikus szakértelmiségi feladat, és kétharmada felsőfokú végzettséget nem igénylő »szaktechnikusi« feladatként jelentkezett. Ebből arra a következtetésre jutottunk, hogy nem a munkát (értsd alatta annak értékét) fizetjük meg, hanem a diplomát. Tehát elvált egymástól a munka valóságos értéke és az azért fizetendő ellenszolgáltatás (fizetés) mértéke”. ${ }^{9}$

Dános Valér: Nincs modern rendészet modern rendészeti vezetés nélkül - új utakon a magyar rendészeti vezetöképzés. Kézirat. Budapest, 1998. 18. 
Az így nyert adatokat, oktatásigazgatási kifejezéssel élve, mint „kimeneti követelményeket" az egyes szaktanszékek rendelkezésére bocsátottuk azzal, hogy fogalmazzák meg, milyen ismeretanyag és milyen óraszám szükséges ahhoz, hogy a végzős hallgatók a kimeneti követelményeknek a képzés végére megfeleljenek. A vizsgálat eredményeiből kiindulva egy kifejezetten praxisorientált, a reális szükségletre épülő moduláris rendszerbe szervezett tanterv készült. Így született meg a Belügyminisztérium vezetésének egyetértésével a kormányrendelet-tervezet, amely A rendvédelmi felsőoktatás képesitési követelményrendszere címet viselte. Ma már tudom, hogy a kormányrendeletbe foglalt tanterv az akkor még nyugatinak nevezett szakirodalomban kompetenciaalapú tantervelméletnek nevezett elveknek sok tekintetben megfelelt. Időm azonban nem volt már a főiskolai képzés megreformálására, tekintettel arra, hogy a belügyminiszter váratlanul, indokolás nélkül visszavonta vezetői megbízásomat, a kormányrendelet-tervezet pedig a fiók mélyére kerülve el sem jutott a javaslati stádiumba. Az igen széles körű empirikus oktatásmódszertani kutatás azonban olyan tapasztalatot és tudást adott számomra, hogy az új beosztásomban, a rendőrségi vezetőképzés intézményesített kiépítését már e modern elmélet ismeretében kezdhettem meg.

És hogy mi lett volna, ha a kormányrendelet-tervezetet 1995. év végén elfogadják és bevezették volna a Főiskolán? Álljon itt válaszként Virányi Gergely volt főiskolai főigazgató-helyettesnek a 2011-ben megjelent Határőrizeti és határrendészeti tisztképzés 1903-2011. című monográfiájából néhány sor:

„Meggyőződésem, tisztelt Olvasó, hogy [...] továbbá Dános dandártábornok, Matei ezredes és Szakács alezredes vezényletével; a négyéves főiskolai tisztképzés 1995-től történő megvalósításával legkevesebb 15 évvel előbbre tartanánk az egyetemi rangú rendészeti felsőoktatás, a rendészettudományos kutatás és innováció, a rendészettudományi tehetséggondozás, a doktori képzés, minősítés és fokozatszerzés, valamint számos rendészeti gyakorlati kérdés tekintetében."10

\section{Utóirat}

A szerzőt azóta is foglalkoztatja az a kérdés, hogy a rendőrtisztképzésnek szükségszerúen Szkülla és Kharübdisz között kell-e hajóznia, avagy egyszer végre elhagyva a szorost, lehorgonyozhat valamelyik móló melletti, biztonságot nyújtó kikötőbe.

10 Virányi Gergely: Határőrizeti és határrendészeti tisztképzés 1903-2011. Budapest, Dialóg Campus, 2019. 429. 


\section{FELHASZNÁLT IRODALOM}

A BM. Rendőrtiszti Akadémia felállításáról szóló, a Magyar Népköztársaság belügyminiszter helyettesének 1960. február 6-án kelt 009. számú utasítása. Online: https://abparancsok.hu/ sites/default/files/parancsok/10_24_9_1960.pdf

Christián László - Erdős Ákos: Vészharang és jubileum? A rendészeti felsőoktatás kilátásai, a tisztjelöltek toborzásának és életpályára állításának nehézségei. Belügyi Szemle, 68. (2020), 12. 11 42. Online: https://doi.org/10.38146/BSZ.2020.12.1

Dános Valér: Nincs modern rendészet modern rendészeti vezetés nélkül - új utakon a magyar rendészeti vezetőképzés. Kézirat. Budapest, 1998.

Györök Ferenc - Kratochwill Ferenc - Nyerges Lajos: A Rendőrtiszti Főiskola múltjáról, jelenéről és jövőjéről. Rendészeti Szemle, 30. (1992), 12. 46-52.

Kratochwill Ferenc: A rendörség szakmai és kulturális színvonala, a rendörképzés. Kézirat. Budapest, 1993.

Nyerges Lajos: Körinterjú a Belügyminisztérium munkájának fejlődéséről (1945-1980). Belügyi Szemle, (1980), 4.

Schubauer László: Büntetőjogi oktatás a felsőfokú rendészeti képzésben. Magyar Rendészet, 14. (2014), 1. 21-26. Online: https://folyoirat.ludovika.hu/index.php/magyrend/article/ view/3999/3266

Szakács Gábor: Összefoglaló jelentés a Rendôrtiszti Főiskola tanárai által kitöltött kérdőivekben szereplő véleményekröl. Kézirat. Budapest, 1994.

Virányi Gergely: Határörizeti és határrendészeti tisztképzés 1903-2011. Budapest, Dialóg Campus, 2019. Online: https://nkerepo.uni-nke.hu/xmlui/bitstream/handle/123456789/13022/Hatarorzeti_es_hatarrendeszeti_tisztkepzes_1903_2011.pdf?sequence=1

\section{ABSTRACT \\ There Was Once a Practice-oriented Training Program Plan at the Police College (1994-1995)}

Valér DÁNOS

The author of this article was the head of the Police College from 1994 to 1996 . He used to be a student at the institution himself, graduating with honours (so-called 'red degree'). Then, for seven years, he was a lecturer and scientific researcher at the institution, and he was able to take part in the development and cultivation of a training program called the complex education system. Directly after the change of regime, as the head of the education department of the Ministry of the Interior, he was responsible for reforming law enforcement education and supervising the organisational system dealing with education. His very extensive knowledge and experience gained in these three areas predestined him to 'reverse' the previous training system immediately after his appointment as head of the College and to implement a practiceoriented training system with a complete paradigm shift instead of what he called speculative curriculum theory training at the Police College. His enthusiasm carried him forward for two years unbroken in the realisation of his vision. He professed with professional conviction and belief that instead of the previously socialist-type knowledge-based approach, it was necessary to introduce practice-oriented training. The elaboration of the idea and its inclusion in the training program was approved by the Minister of the Interior of that time, with significant recognition. 
The few months later newly appointed Minister of the Interior confirmed the assignment of the College Commander and ordered the proposal to be included in the curriculum. Thus, the innovation work that was started could continue with the cooperation of an enthusiastic team (including Gábor Szakács, PhD, László Matei, PhD, Béla Blaskó, PhD, István Révész and others) who lined up next to the head of the College. The following article presents some of the data of the scientifically based, extensive unpublished empirical research, and the main characteristics of the stations of the creation of a new curriculum. At the end of his writing, the author also discusses the further fate of the curriculum of the new training, of the draft government decree introducing the new curriculum and of the College Commander.

Keywords: police officer training, innovation, practice orientation, anniversary, Police College 